\title{
PENGARUH BIAYA CORPORATE SOCIAL RESPONBILITY TERHADAP NET INCOME PT. ANTAM
}

\author{
Kurniawan Tarmizi \\ PT. ANTAM, Tbk \\ Email: tarmizi.kurniawan@gmail.com
}

\begin{abstract}
Abstrak
Tujuan penelitian adalah untuk mengetahui pengaruh CSR terhadap kinerja keuangan yan diukur dengan Net Income baik secara parsial maupun secara simultan.Tema pengungkapan CSR sebagai variabel Independen dibagi menjadi tiga tema yaitu lingkungan, kesehatan, masyarakat.

Populasi dalam penelitian ini menggunakan satu perusahaan, dengan periode tiga tahun 2012,2013, 2014. Teknik analisis data yang digunakan adalah uji asumsi klasik dan reglesi linear berganda yang dilakukan secara parsial maupun simultan dengan menggunakan software SPSS 20.0.

Hasil analisis secara parsial menunjukkan bahwa variable lingkungan,kesehatan, masyarakat tidak berpengaruh secara signifikan terhadap kinerja keuangan perusahaan,pengujian secara simultan menyatakan bahwa lingkungan kesehatan masyarakat secara bersama-sama tidak berpengaruh secara signifikan terhadap kinerja keuangan perusahaan.
\end{abstract}

Kata kunci: CSR, lingkungan, keehatan, masyarakat.

\section{Abstrack}

The purpose of this research is to know the effect of CSR to finance performance that was measure by using Net Income with parcial even simultaneous. The theme of using CSR as independent variable is devided into three themes such as environment, healthy and society.

The population of this research is used an enterprise with three years 2012, 2013, 2014. The data analysis technique used is classic test assumption and double reglesi linear that was done partially even simultaneous by using software SPSS 21.0.

The partial analysis result shows that environment variable, healthy, society doesn't have a significant effect to an enterprise finance performance, the simultaneous result shows that the environment, healthy and society as one doesn't have a significant effect to an enterprise financeperformance.

Keyword: CSR, Environment, healty, society.

\section{PENDAHULUAN}

Perkembangan dunia bisnis saat ini mengalami peningkatan yang sangat pesat serta persaingan yang sangat ketat.Saat perusahaan semakin berkembang,maka tingkat 
kesenjangan sosial dan kerusakan lingkunganpun semakin tinggi karena adanya aktivitas perusahaan yang tidak terkendali terhadap berbagai sumber daya untuk meningkatkan laba perusahaan.Selain pihak yang terkait langsung dengan perusahaan,masyarakat dan lingkungan sekitar perusahaan pun merasakan dampak yang di timbulkan oleh aktivitas operasi perusahaan. Oleh sebab itu, tanggungjawab perusahaan tidak hanya kepada para shareholder tetapi juga kepada pihak-pihak yang memiliki kepentingan dengan perusahaan seperti pelanggan, pemilik atau investor,supplier,komunitas dan juga pesaing (Rika dan Islahuddin,2008).

Seperti kita ketahui bahwa Corporate Social Responsibility (CSR) merupakan suatu pertanggung jawaban yang diberikan oleh perusahaan untuk memenuhi kebutuhan para stakeholder internal maupun eksternal.CSR telah ada sejak tahun 1800-an yang lebih di kenal dengan nama Occupational Social Worker, Social Work in The Workplace,Employee Assistance yang bisa di sebut juga dengan Pekerjaan Sosial Industri (PSI) (Smith, 1998:Zastrow, 2000 dalam putra, 2012). Inggris, Jerman dan AS telah melakukan (PSI) sejak tahun 1890 sedangkan Perancis sejak tahun 1920.Di dalam PSI inilah terdapat berbagai bentuk programCSR baik berupa strategi maupun program pengembangan masyarakat. Seiring berjalanya waktu,CSR pun turut berkembang dengan pesat. Perkembangan tersebut di tandai dengan cepatnya penyebaran suatu berita dalam dunia bisnis.Melalui berita yang cepat maka akan cepat pula timbul reaksi pasar terhadap suatu perusahaan yang berpengaruh terhadap nilai perusahaan. Tiap-tiap perusahaan sudah melaporkan pelaksanaan tanggung jawab sosial yang telah dilakukan di dalam laporan tahunan namun sifatnya masih sukarela.Hal ini dikarenakan oleh adanya pertimbangan perusahaan terhadap biaya yang di keluarkan untuk menerapkan biaya CSR dan manfaat yang nantinya akan di hasilkan setelah melakukan pengungkapan informasi sosial.Jika manfaat yang di peroleh lebih besar dari biaya yang dikeluarkan untuk pengungkapan sosial perusahaan maka dengan sukarela perusahaan akan mengungkapkan informasi sosial perusahaan.

Adanya pertimbangan perusahaan terhadap biaya yang dikeluarkan untuk menerapkan CSR mengindikasikan bahwa perusahaan masih lebih mengedepankan sisi keuangan di bandingkan sisi non keuangan.CSR yang paling umum diberikan adalah pemberian bantuan berupa sumbangan dan dilakukan hanya sekedar untuk berbuat baik demi terlihat baik di mata masyarakat (do good and to look good). Banyaknya kasus-kasus yang terjadi terkait dengan lingkungan yang dilakukan oleh perusahaan yang berdampak pada masyarakat dan lingkungan.Seperti kasus lumpur Lapindo yang terjadi daerah Sidoarjo yang dinobatkan sebagai perusahaan yang tidak bertanggungjawab, pencemaran Teluk Buyat oleh PT. Newmont Minahasa Raya dan kasus pencemaran yang dilakukan oleh PT. Freeport Indonesia yang dinilai tidak memenuhi batas air limbah dan telah mencemari biota laut (Arifin dkk, 2012).Kasus-kasus tersebut memberikan gambaran bahwa perusahaan sesungguhnya juga perlu memperhatikan sisi non keuangan terutama dari sisi lingkungan dan sosial.

Menyadari bahwa pentingnya suatu perusahaan memperhatikan sisi lingkungan dan sosial maka akhirnya perusahaan pun mulai menerapkan CSR. Hal ini dapat dilihat dari di majalah SWA pada tahun 2005 menyatakan bahwa program tanggung jawab sosial masih di dominasi oleh program sosial sebanyak $49,53 \%$, lingkungan dengan $25,70 \%$, dan keuangan 
24,76\% (Pambudi, 2006).Dari fakta tersebut dapat kita ketahui bahwa segala kegiatan perusahaan tidak hanya berpatokan pada aspek keuangan namun juga sangat berpengaruh terhadap lingkungan sekitar dan masyarakat.

Pada akhirnya di tahun 2007 pemerintah indonesia menerbitkan regulasi yang mengatur tentang CSR yaitu Undang-Undang No.40 tahun 2007 tentang perseroan terbatas dalam pasal 74 menyebutkan bahwa:

(1) "Perseroan yang menjalankan kegiatan usahanya di bidan dan atau berkaitan dengan sumber daya alam wajib melaksanakan tanggungjawab sosial dan lingkungan".

(2) "Merupakan kewajiban perseroan yang dianggarkan dan perhitungan sebagai biaya perseroan yang pelaksaanya dilakukan dengan memperhatikan kepatutan dan kewajaran".

(3) "Perseroan yang tidak melaksanakan kewajiban dikenai sanksi sesuai dengan ketentuan peraturan perundang-undangan" (www.hukumonline.com).

Dengan adanya ini,perusahaan khususnya perseroan terbatas yang bergerak di bidan dan atau berkaitan dengan sumber daya alam harus melaksanakantanggung jawab sosial kepada masyarakat.

Sanksi pidana mengenai pelanggaran CSR pun terdapat di undang-undang Nomor 23 Tahun 1997 tentang pengelolaan Lingkungan hidup (UUPLH) Pasal 41 ayat (1) yang menyatakan : "Barangsiapa yang melawan hukum dengan sengaja melakukan perbuatan yang mengakibatkan pencemaran dan atau perusakan lingkungan hidup,diancam dengan pidana penjara paling lama sepuluh tahun dan denda paling banyak lima ratus juta rupiah". Selanjutnya pasal 42 ayat (1) menyatakan ; "Barangsiapa yang karena kealpaanya melakukan perbuatan yang mengakibatkan pencemaran dan atau perusakan lingkungan hidup,diancam dengan pidana penjara paling lama tiga tahun dan denda paling banyak seratus juta rupiah" (Sutopoyudo, 2009).

CSR tidak lagi dihadapkan pada tanggung jawab yang berpijak pada single bottom line, yaitu nilai perusahaan (corporate value) yang direfleksikan dalam kondisi keuanganya(financial) saja.Tapi tanggung jawab perusahaan harus berpijak pada triple bottom lines. Disini bottom lines lainya selain finansial juga ada sosial dan lingkungan,karena kondisi keuangan saja tidak cukup menjamin nilai perusahaan tumbuh secara berkelanjutan (sustainable).

Keberlanjutan perusahaan hanya akan terjamin apabila perusahaan memperhatikan dimensi sosial dan lingkungan hidup.Sudah menjadi fakta bagaimana resistensi masyarakat sekitar diberbagai tempat dan waktu muncul ke permukaan terhadap perusahaan yang dianggap tidak memperhatikan aspek-aspek sosial,ekonomi dan lingkungan hidupnya.

Masyarakat sekarang lebih pintar dalam memilih produk yang akan mereka konsumsi.Sekarang masyarakat cenderung untuk memilih produk yang diproduksi oleh perusahaan yang peduli terhadap lingkungan atau melaksanakan CSR. Survei yang dilakukan Booth-Harris Trust Monitor pada tahun 2001 dalam Sutopoyudo (2009) menunjukan bahwa mayoritas konsumen akan meninggalkan suatu produk yang mempunyai citra buruk atau diberitakan negatif.Banyak manfaat yang diperoleh perusahaan dengan pelaksanaan Corporate Social Responsibility,antara lain produk semakin disukai oleh konsumen dan perusahaan diminati oleh investor.Corporate Social Responsibility dapat digunakan sebagai alat marketing baru bagi perusahaan bila itu dilaksanakan berkelanjutan.Untuk melaksanakan CSR berarti perusahaan akan mengeluarkan sejumlah 
biaya.Biaya pada akhirnya akan menjadi beban yang mengurangi pendapatan sehingga tingkat profit perusahaan akan turun.Akan tetapi dengan melaksanakan CSR,citra perusahaan akan semakin baik sehingga loyalitas konsumen makin tinggi.Seiring meningkatnya loyalitas konsumen dalam waktu yang lama,maka penjualan perusahaan akan semakin membaik dan pada akhirnya dengan pelaksanaan CSR,diharapkan tingkat profitabilitas perusahaan juga meningkat (Satyo, 2005 dalam Sutopoyudo).Oleh karena itu, CSR berperan penting dalam meningkatkan nilai perusahaan sebagai hasil dari peningkatan penjualan perusahaan dengan cara melakukan berbagai aktivitas sosial di lingkungan sekitarnya.

Menurut Darwin (2004) dalam Rakhiemah dan Agustia (2009)perusahaan dapat memperoleh banyak manfaat dari praktik dan pengungkapan CSR apabila di praktekan dengan sungguhsungguh, diantaraanya: dapat mempererat komunikasi dengan stakeholders,meluruskan visi, misi dan prinsip perusahaan terkait dengan praktek dan aktivitas bisnis internal perusahaan,mendorong perbaikan perusahaan secara berkesinambungan sebagai wujud manajemen resiko dan untuk melindungi reputasi,serta untuk meraih competitive advantage dalam hal modal,tenaga kerja,supplier dan pangsa pasar.

Penelitian ini mengacu pada penelitian Nurlela dan Islahuddin (2008) yang dahulu meneliti tentang pengaruh biaya Corporate Social Responsibility terhadap Net Income perusahaan pada periode tahun 2005 dan digunakannya kepemilikan manajemen sebagai variabel moderating. Perbedaan dengan penelitian sebelumnya yaitu menggunakan tiga parameter CSR, yaitu lingkungan, kesehatan, masyarakat.

\section{Perumusan Masalah}

Berdasarkan Latar belakang di atas, maka rumusan masalah yang dibuat adalah :

1. Bagaimana pengaruh biaya CSR (Lingkungan, Kesehatan, masyarakat) secara parsial terhadap Net Incomeperusahaan?

2. Bagaimana pengaruh biaya CSR (Lingkungan, kesehatan, masyarakat) secara simultan terhadap Net income perusahaan?

3. CSR parameter manakah yang mempunyai pengaruh terbesar terhadap Net Income perusahaan?

\section{LANDASAN TEORI}

\section{Corporate Social Responbility}

Konsep tanggung jawab sosial perusahaan telah mulai dikenal sejak awal 1970an, yang secara umum dikenal dengan stakeholdertheory artinya sebagai kumpulan kebijakan dan praktik yang berhubungan dengan stakeholder, nilai-nilai, pemenuhan ketentuan hukum, penghargaaan masyarakat dan lingkungan, serta komtimen dunia usaha untuk berkontribusi dalam pembangunan secara berkelanjutan. Stakeholder theory dimulai dengan asumsi bahwa nilai (value) secara explisit dan tang dipungkiri merupakan bagian dari

usaha (freema, et al,.2002 dalam Waryanti, 2009).

Teori Stakeholder mengatakan bahwa bahwa perusahaan bukanlah entitas yang hanya beroperasi untuk berkepentingan sendiri namun harus memberikan manfaat bagi stakeholdernya.Dengan demikian, keberadaan perusahaan sangat dipengaruhi oleh dukungan yang diberikan kepada perusahaan stakeholder kepada perusahaan tersebut (Ghozali dan Chariri, 2007). 
Tanggung jawab sosial perusahaan seharusnya melampaui tindakan memaksimalkan laba untuk kepentingan pemegang saham (stakeholder), namun lebih luas lagi bahwa kesejahteraan yang dapat diciptakan oleh perusahaan sebetulnya tidak terbatas kepentingan pemegang saham, tetapi juga untuk kepentingan stakeholder, yaitu semua pihak yang mempunyai keterkaitan atau klaim terhadap perusahaan (Untung, 2008 dan Waryanti, 2009). Mereka adalah pemasok, pelanggan dan pemerintah, masyarakat lokal, investor, karyawan, kelompok politik dan asosiasi perdagangan.Seperti halnya pemgang saham yang mempunyai hak terhadap tindakan-tindakan yang dilakukan perusahaan, stakeholder juga mempunyai hak terhadap perusahaan. (Waryanti, 2009) Stakeholder pada dasarnya dapat mengendalikan atau memiliki kemampuan untuk mempengaruhi pemakaian sumber-sumber ekonomi yang digunakan perusahaan. Oleh karena itu power stakeholder ditentukan oleh besar kecilnya power yang dimiilki stakeholder atas sumber tersebut (Ghozali dan Chariri, 2007). Power tersebut dapat berupa kemampuan untuk membatasi

pemakaian sumber ekonomi yang terbatas (modal dan tenaga kerja. Akses terhadap media yang berpengaruh kemampuan untuk mengatur perusahaan atau kemampuan untuk mmpengaruhi konsumsi atas barang dan jasayang dihasilkan perusahaan (Deegan 2000, dalam Ghozali dan Chariri, 2007). Oleh karena itu, ketika stakeholder mengendalikan sumber ekonomi yang penting bagi perusahaan maka perusahaan akan bereaksi dengan cara yang memuaskan keinginan stakeholder (Ullman 1982 hal.552 dalam Ghozali dan Chariri, 2007).

Atas dasar argumen diatas, teori stakeholder umumnya berkaitan dengan cara-cara yang digunakan perusahaan untuk memanage stakeholder (Gray, et al.,1997 dalam Ghozali dan Chariri, 2007). Cara-cara yang dilakukan perusahaan untuk memanage stakeholdernya tergantung pada strategi yang diadopsi perusahaan (Ullman, 1985 dalam Ghozali dan Chariri, 2007).Organisasi dapat mengadopsi strategi aktif atau pasif(Ullman 1985 dalam Ghozali dan Chariri, 2007) mengatakan strategi aktif adalah apabila perusahaan berusaha mempengaruhi hubungan organisasinya dengan stakeholder yang dipandang

berpengaruh atau penting.Sedangkan perusahaan yang mengadopsi startegi pasif yang cenderung tidak terus-menerus memonitor stakeholder dan secara tidak sengaja tidak mencari strategi optimal untuk menarik perhatian stakeholder.Akibat dari kurangnya perhatian dari stakeholder adalah rendahnya tingkat pengungkapan informasi sosial dan rendahnya sosial perusahaan.

\section{Pertanggungjawaban Sosial Perusahaan}

Pertanggungjawaban sosial perusahaan atau Corporate Social Responbility (CSR) adalah mekanisme bagi suatu oprganisasi untuk secara sukarela mengintegrasikan perhatian terhadap lingkungan dan sosial kedalam operasinya dan interkasinya dengan stakeholdersyang melebihi tanggungjawab organisasi dibidang hukum (Darwin 2004 dalam Anggraini 2006).

Menurut TheWorld Business Council for SustainableDevelopment(WBCSD), CSR perusahaan didefinisikan sebagai komitmen bisnis untuk memberikan kontribusi bagi pembangunan ekonomi berkelanjutan, melalui kerja sama dengan para karyawan serta perwakilan mereka, keluarga mereka, komunitas setempat maupun masyarakat umum untuk meningkatkan kualitas kehidupan dengan cara yang bermanfaat baik bagi bisnis sendiri maupun untuk pembangunan. 
Pertanggungjawaban sosial perusahaan diungkapakan didalam laporan yang disebut Sustainability Reporting.Sustainability Reporting adalah pelaporan mengenai kebijakan ekonomi, lingkungan dan sosial, pengaruh dan kinerja organisasi dan produknya di dalam konteks pembangunan berkelanjutan (Sutainable development).Sustainability Reporting meliputi, pelaporan mengenai ekonomi, lingkungan dan pengaruh sosial terhadap kinerja organisasi (ACCA, 2004 dalam Anggaraini,2006).Sustainability Report harus menjadi dokumen strategic yang berlevel tinggi yang menempatkan isu, tantangan dan peluang sustainable development yang membawanya menuju kepada core business dan sektor industrinya.

Berkaitan dengan pelaksanaan CSR, perusahaan bisa dikelompokan kedalam beberapa kategori.Meskipun cenderung menyederhanakan realitas,tipologi ini menggambarkan kemampuan dan komitmen perusahaan dalam menjalankan CSR.Pengkategorian dapat memotivasi perusahaan dalam mengembangkan program CSR dan dapat pula dijadikan cermin dan guideline untuk menentukan model CSR yang tepat(soeharto, 2007).

Dengan menggunakan dua pendekatan setidaknya ada 8 kategori perusahaan.Perusahaan ideal memiliki kategori reformis dan progresif. Tentu saja dalam kenyataanya, kategori ini bisa saja saling bertautan.

1. Berdasarkan proporsi keuntungan perusahaan dan besarnya anggaran CSR

a. Perusahaan Minimalis. Perusahaan yang memiliki profit dan anggaran CSR yang rendah. Perusahaan kecil dan lemah biasanya termasuk kategori ini.

b. Perusahaan Ekonomis. Perusahaan yang memiliki keuntungan tinggi, namun anggaran CSRnya rendah. Perusahaan yang termasuk perusahaan ini di sebut perusahaan besar, namun pelit.

c. Perusahaan Humanis. Meskipun profit perusahaan rendah, proporsi anggaran CSR nya relative tinggi. Perusahaan pada kategori ini disebut perusahaan dermawan atau baik hati.

d. Perusahaan Reformis. Perusahaan ini memiliki profit dan anggaran CSR yang tinggi. Perusahaan seperti ini memandang CSR bukan sebagai beban, melainkan sebagai peluang untuk lebih maju.

2. Berdasarkan tujuan CSR apakah untuk promosi atau pemberdayaan masyarakat

a. Perusahaan Pasif. Perusahaan yang menerapkan CSR tanpa tujuan jelas, bukan untuk promosi, bukan pula untuk pemberdayaan, sekedar melakukan kegiatan karitatif. Perusahaan seperti ini melihat promosi dan CSR sebagai hal yang kurang bermanfaat bagi perusahaan.

b. Perushaan Impresif. CSR lebih di utamakan untuk promosi daripada untuk pemberdayaan. Perusahaan seperti ini lebih mementingkan "tebar pesona" daripada "tebar karya".

c. Perusahaan Agresif. CSR lebih ditujukan untuk pemberdayaan daripada promosi. Perusahaan seperti ini lebih mementingkan karya nyata daripada tebar pesona.

d. Perusahaan Progresif. Perusahaan menerapkan CSR untuk tujuan promosi dan sekaligus pemberdayaan. Promosi dan CSR dipandang sebagai kegiatan yang bermanfaat dan menunjang satu sama lain bagi perusahaan. 
3. Pengungkapan Tanggung Jawab Sosial Perusahaan. Menurut Martin Freedman, dalam Henny dan Murtanto (2001) dalam Kuntari dan Sulistyani (2007), ada dua pendekatan dalam pelaporan kinerja sosial, yaitu :

1. Pemeriksaan Sosial (Social Audit)

Pemeriksaaan sosial mengukur dan melaporkan dampak ekonomi, sosial dan lingkungan dari program-program yang berorientasi sosial dari operasi-operasi yang dilakukan perusahaan. Pemeriksaan sosial dilakukan dengan membuat suatu daftar aktivitas-aktivitas perusahaan yang memiliki konsekuensi sosial, lalu auditor sosial akan mencoba mengestimasi dan mengukur dampak-dampak yang ditimbulkan oleh aktivitas-aktivitas

tersebut.

2. Laporan Sosial (Sosil Report)

Berbagai alternative format laporan untuk menyajikan laporan sosial telah diajukan oleh para akademis dan praktisioner.Pendekatan-pendekatan yang dapat dipakai oleh perusahaan untuk melaporkan aktivitas-aktivitas pertanggungjawaban sosialnya ini dirangkum oleh Dilley dan Weygandt menjadi empat kelompok sebagai berikut (Henry dan Murtanto, 2001 dalam Kuntari dan Sulistyani, 2007).

1. Inventory Approach

Perusahaanmengkomplikasikan dan mengungkapan sebuah daftar yang komprehensif dari aktivitas-aktivitas sosial perusahaan.Daftar ini harus memuat semua aktivitas sosial perusahaan baik yang bersifat positif maupun negative.

2. Cost Approach

Perusahaan membuat daftar aktivitas-aktivitas sosial perusahaan dan mengungkapkan jumlah pengeluaran pada masing-masing aktivitas tersebut.

3. Program Management Approach

Perusahaan tidak hanya mengungkapkan aktivitas-aktivitas pertanggungjawaban social tetapi juga tujuan dari aktivitas tersebut serta hasil yang telah dicapai oleh perusahaan sesuai dengan tujuan yang telah ditetapkan itu.

4. Cost Benefit Approach

Perusahaan mengungkapkan aktivitas yang memiliki dampak sosial serta biaya dan manfaat dari aktivitas tersebut.Kesulitan dalam penggunaan pendekataan ini adalah adanya kesulitan dalam mengukur biaya dan manfaat sosial yang diakibatkan oleh perusahaan terhadap masyarakat.

\section{Pengungkapan Sosial dalam Laporan Tahunan (Disclosure In Annual Report)}

Pengungkapan sosial adalah pengungkapan informasi tentang aktivitas perusahaan yang berhubungan dengan lingkungan sosial perusahaan. Pengungkapan sosial dapat dilakukan melalui berbagai media antara lain laporan tahunan, laporan interim/laporan sementara, prospektus, pengumuman kepada bursa efek atau melalui media massa. Perusahaan cenderung untuk mengungkapkan informasii yang berkaitan dengan aktivitasnya dan dampak yang ditimbulkan oleh perusahaan tersebut.

\section{Tema pengungkapan CSR}

Hendriksen (1991:203) mendefinisikan pengungkapan sebagai penyajian sejumlah informasi yang dibutuhkan untuk pengoprasian secara optimal pasar modal yang efisien. 
Pengungkapan ada yang bersifat wajib yaitu mengungkapakan informasi wajib dilakukan oleh perusahaan yang didasarkan pada $\mathrm{p}$ eraturan atau standar tertentu dan ada yang bersifat sukarela yang merupakan pengungkapan informasi melebihi persyaratan minimum dari peraturan yang berlaku. Pengungkapan tema atau parameter CSR menurut Brammer (2005), syekti dan wondabio (2007), dan sembiring (2005) meliputi tujuh parameter:

a. Lingkungan

Tema ini meliputi aspek lingkungan dari proses produksi, yang meliputi pengendalian polusi dalam menjalankan operasi bisnis, pencegahan dan perbaikan kerusakan lingkungan akibat pemerosesan sumber daya alam dan konversi sumber daya alam.

b. Kesehatan

Tema ini membahas tentang kesehatan dan keselamatan kerja karyawan mulai dari perisapan proses produksi, proses produksi itu sendiri, sampai kegiatan pasca produksi dan melakukan evaluasi secara peningkatan kesehatan dan keselamatan kerja.

c. Masyarakat

Tema ini mencakup aktifitas kemasyarakatan yang di ikuti ataupun dilakukan oleh perusahaan, misalanya aktifitas yang terkait dengan kesehatan, pendidikan, dan seni serta pengungkapan aktifitas kemasyarakatan lainya.

\section{Kinerja Keuangan}

Kinerja keuangan merupakan gambaran pencapaian keberhasilan perusahaan dapat diartikan sebagai hasil yang telah dicapai atas berbagai aktivitas yang dilakukan dapat dijelaskan bahwa kinerja keuangan bahwa suatu analisis yang dilakukan untuk melihat sejauh mana suatu perusahaan telah melaksanakan dengan menggunkan aturan-aturan pelaksanaan keuangan secara baik dan benar (Fahmi, 2012; 2).

Net Income Sebagai Pengukur Kinerja Keuangan Perusahaan Commite On Terminology (Sofyan Syafri H.,2004) dalam Aliyal Azmi (2007:12) mendefinisikan laba sebagai jumlah yang berasal dari pengurangan harga pokok produksi, biaya lain dan kerugian dari penghasilan atau penghasilan operasi. Menurut Stice, Stice, Skousen (2009:240) laba adalah pengambilan atas investasi kepada pemilik. Hal ini mengukur nilai yang dapat diberikan oleh entitas kepada investor dan entitas masih memiliki kekayaan yang sama dengan posisi awalnya. Menurut Suwardjono (2008 : 464) laba dimaknai sebagai imbalan atas upaya perusahaan menghasilkan barang dan jasa. Ini berarti laba merupakan

kelebihan pendapatan diatas biaya (biaya total yang melekat dalam kegiatan produksi dan penyerahan barang / jasa). Menurut Soemarso SR (2004 : 227) angka terakhir dalam laporan laba rugi adalah Laba Bersih (net income). Jumlah ini merupakan kenaikan bersih terhadap modal.Sebaliknya, apabila perusahaan menderita rugi, angka terakhir dalam laporan laba rugi adalah rugi bersih (net loss).

Menurut Smith Skousen (1989:119) Laba Bersih merupakan perbedaan antara jumlah pendapatan yang diperoleh suatu satuan usahan selama periode tertentu dan jumlah biaya yang dapat diaplikasikan kepada pendapat. Belkaoui (1993) Laba merupakan suatu pos dasar dan penting dari ikhtisar keuangan yang merniliki berbagai kegunaan dalam berbagai konteks.Laba pada umumnya dipandang sebagai suatu dasar bagi perpajakan, determinan pada kebijakan pembayaran dividen, pedoman investasi, dan pengambilan keputusan, dan unsur prediksi. Rahmat (2006:9) Laba dipandang sebagai suatu peralatan prediktif yang membantu dalam peramalan laba mendatang dan peristiwa ekonomi yang akan 
datang. Laba terdiri dari hasil operasional, atau luar biasa, dan hasil-hasil non-operasional, atau keuntungan dan kerugian luar biasa, dimana jumlah keseluruhannya sama dengan laba bersih. Laba biasa dianggap bersifat masa kini (current) dan berulang, sedangkan keuntungan dan kerugian luar biasa tidak demikian. (IAI, 1994) mengartikan penghasilan (income) adalah kenaikan manfaat ekonomi selama suatu periode akuntansi dalam bentuk pemasukan atau penambahan aktiva atau penurunan kewajiban yang mengakibatkan kenaikan ekuitas yang tidak berasal dari kontribusi penanam modal.

\section{Penelitian terdahulu}

1. Yuniarti (2003) dalam Nurlela \& Islahuddin (2008) meneliti tentangpengungkapan informasi pertanggungjawaban sosial pada perusahaan yang terdaftar di BEJ, dengan mengambil sampel seluruh perusahaan yang terdaftar di BEJ sebelum tanggal 31 Desember 2000. Hasil penelitian tersebut menemukan bahwa (1) Tingkat pengungkapan pertanggungjawaban sosial pada perusahaan yang terdaftar di BEJ ternyata sangat rendah. Hal ini terlihat dari rendahnya nilai yang di peroleh sampel jika dibandingkan dengan maksimal skor yang dapat diperoleh. (2) Ukuran perusahaan mempengaruhi tingkat pengungkapan pertanggungjawaban sosial perusahaan-perusahaan yang terdaftar di BEJ, walaupun pengaruh tersebut di kategorikan rendah sebesar 7,8\%. (3) Setiap jenis industri berbeda dalam melakukan pengungkapan pertanggungjawaban sosial.

2. Paranita (2007) Meneliti tentang Pengaruh insider ownership, kebijakan hutang, profitabilitas dan ukuran perusahaan terhadap nilai perusahaan, dengan sampel seluruh perusahaan manufaktur yang go publik dan listing di Bursa Efek Jakarta periode tahun 2001-2005. Purposive sampling dengan sampel penuh (full sample) digunakan dalam penelitian ini. Jumlah perusahaan publik yang terdaftar di BEJ hingga tahun 2005 adalah 339 emiten, berdasarkan kriteria-kriteria purposive sampling dari populasi tersebut didapatkan 109 emiten yang memenuhi syarat-syarat sebagai sampel. Hasil penelitian ini menunjukan bahwa insider ownership, kebijakan hutang, profitabilitas dan ukuran perusahaan secara simultan berpengaruh positive dan signifikan terhadap nilai perusahaan.

3. Soliha (2002) Dalam paranita (2007) Meneliti tentang insider ownership,profitabilitas dan ukuran perusahaan, dengan mengambil sampel seluruh perusahaan yang telah listed sejak 1992-1996. Menggunakan path diagram dalam menganalisis determinan nilai perusahaan dan menyimpulkan bahwa insider ownership, profitabilitas dan ukuran perusahaan berpengaruh positive dan signifikan terhadap nilai perusahaan.

4. Nurlela \& Islahuddin (2008) Meneliti tentang pengaruh CSR terhadap nilai perusahaan dengan kepemilikan manajemen sebagai variable moderating dengan mengambil sampel perusahaan-perusahaan sektor nonkeuangan yang terdaftar di BEJ untuk tahun 2005. Berdasarkan Indonesian Capital Market Directory perusahaan yang terdaftar di BEJ selama tahun 2005 berjumlah 340 perusahaan setelah diolah hanya menggunakan 41 perusahaan di dalam penelitian. Hasil penelitian ini menunjukan bahwa CSR, Persentase kepemilikan,serta interaksi antar CSR dengan presentase kepemilikan manajemen secara simultan berpengaruh signifikan terhadap nilai perusahaan.

5. Anggraini (2006) Meneliti tentang pengungkapan informasi sosial dalam laporan keuanagan tahunan (Studi Empiris pada perusahaan-perusahaan yang terdaftar Bursa Efek Jakarta). Meneliti tentang faktor-faktor yang mempengaruhi pengungkapan 
informasi sosial faktor-faktor yang di uji pengaruhnya terhadap kebijkan perusahaan dalam melakukan pengungkapan informasi sosial adalah porsentase kepemilikan manajemen, tingkat leverage, biaya politis, dan profitabilitas.Porsentase kepemilikan manjemen diukur dengan porsentase sahamyang dimiliki manajemen tingkat laverage di ukur dengan rasio utang/ekuitas, biaya politis diproksi dengan dua variable yaitu ukuran perusahaan yang diukur dengan kapitalisasi pasar, dan tipe industri yang diukur dengan variable dummy, variable terakhir yaituprofitabilitas diukur dengan net profit margin.

\section{Kerangka Pemikiran}

\section{Pengaruh Biaya CSR Terhadap Net Income Perusahaan}

Dalam menjalankan kegiatan operasinya, perusahaan berhadapan dengan banyak stakeholdersseperti karyawan, pemasok, investor, pemerintah, konsumen, serta masyarakat. Untuk mempertahankan eksistensinya perusahaan memerlukan dukungan stakeholders sehingga aktivifitas perusahaan harus mempertimbangkan persetujuan dari stakeholders. Semakin kuat stakeholders, maka perusahaan harus semakinberadaptasi dengan stakeholders.Berdasarkan teori stakeholders, perusahaan memilih untuk menanggapi banyak tuntutan yang dibuat oleh para pihak yang berkepentingan (stakeholders), yaitu setiap kelompok dalam lingkungan luar organisasi yang terkena tindakan dan keputusan organisasi. Diharapkan dengan memenuhi tuntutan para stakeholders dapat meningkatakan penghasilan perusahaan. Penelitian yang mendukung adanya hubungan anatara CSR dengan kinerja perusahaan adalah penelitian Dahlia dan Siregar (2008) yang menunjukan bahwa aktivitas CSR berpengaruh positive terhadap Net Income.

Aktivitas CSR yang dilakukan oleh perusahaan akan berdampak terhadap kinerja perusahaan sesuai dengan penelitian dahlia dan siregar (2008). Penelitian ini meneliti pengaruh aktivitas CSR terhadap ROE 1 tahun kedepan karena aktivitas CSR berdampak secara tidak langsung terhadap kinerja perusahaan. Hal ini karena diduga aktivitas CSR dapat menjadi elemen yang menguntungkan sebagai starategi perushaan, memberikan

kontribusi kepada manajemen resiko dan memelihara hubungan yang dapat memberikan keuntungan jangka panjang bagi perusahaan sesuai dengan penelitian Heal dan Garret (2004).

\section{HIPOTESIS}

Ha1: Biaya CSR (Lingkungan,kesehatan,masyarakat), berpengaruh terhadap Net Income perusahaan.

Ha2: Biaya CSR (Lingkungan,kesehatan,masyarakat) secara bersama-sama, berpengaruh terhadap Net Income perusahaan.

Ha3: Biaya CSR (Lingkungan ), berpengaruh signifikan terhadap Net Income perusahaan.

\section{METODOLOGI PENELITIAN}

\section{Populasi dan Sampel}

Populasi dalam penelitian ini adalah perusahaan PT Antam yang terdaftar di Bursa Efek Indonesia. Sedangkan untuk penentuan sample dipilih dengan menggunakan metode purposive sampling dengan kriteria :

1. Perusahaan tersebut tercatat di Bursa Efek Indonesia tahun $(2013,2014,2015)$.

2. Perusahaan mencantumkan laporan pertanggungjawaban sosial dalam annual report tahun $(2013,2014,2015)$ dan data yang disajikan lengkap.

\section{Metode Pengumpulan Data}


Pengumpulan data dilakukan dengan cara menelusuri laporan tahunan yang terpilih menjadi sampel. Sebagai panduan digunakan instrument penelitian berupa check list data daftar pertanyaan-pertanyaan yang berisi item-item pengungkapan pertanggungjawaban sosial.

\section{Metode Analisis Data dan Pengujian Hipotesis}

Uji Asumsi Klasik (Normalitas, Multikolinearitas,teroskedastisitas, autokorelasi), uji regresi berganda dengan uji t dan uji f.

$$
\mathrm{NI}=\beta 0+\beta 1 \text { lingkungan }+\beta 2 \text { kesehatan }+\beta 3 \text { masyarakat }+\varepsilon i t
$$

\section{ANALISA HASIL}

Hasil uji statistik asumsi klasik menunjukkan indikator setiap variabel tidak ada yang menunjukkan gejala penyakit asumsi klasik.

\section{Hasil pengujian Regresi Linier Berganda}

Dalam penelitian ini dilakukan anlisis regresi untuk mengetahui ada tidaknya pengaruh antar variable independen terhadap variable dependen. Dengan demikian persamaan regresi yang digunakan adalah

$$
\mathrm{ROE}=\beta 0+\beta 1 \text { Lingkungan }+\beta 2 \text { Kesehatan }+\beta 3 \text { Masyarakat }+ \text { eit. }
$$

Dari analisis regresi dengan menggunakan proses SPSS di peroleh hasil seperti dalam table. Berdasarkan table persamaan regresi yang dapat

disusun adalah Net Income $=-14318408,407-3,688$ CSR lingkungan $+2,498$ CSR masyarakat,+ 944 CSR kesehatan + eit.

Hasil uji t hanya berpengaruh pada indicator lingkungan, selain itu tidak signifikan.

Hasil pengujian dapat di terjemahkan sebagai berikut:

a. Variabel Lingkungan memiliki nilai t sebesar 5,757 dengan tingkat signifikan 0,000 lebih kecil dari a 0,05 (5\%). Hal ini menunjukan bahwa tanggung jawab social perusahaan di bidang lingkungan berpengaruh signifikan terhadap Net Income perusahaan. Dengan demikian, hipotesisi alternative (HA1) yang menyatakan bahwa CSR lingkungan berpengaruh terhadap Net Income diterima.

b. Variabel Masyarakat memilik nilai t sebesar1,320 dengan tingkat signifikan 0,198 lebih besar dari a 0,05 (5\%). Hal ini menunjukan bahwa tanggung jawab social perusahaan di bidang Masyarakat tidak berpengaruh signifikan terhadap Net Income perusahaan. Dengan demikian, hipotesis alternative (HA2) yang menyatakan bahwa CSR masyarakat berpengaruh terhadap Net Incomeditolak.

c. Variabel Kesehatan memiliki nilai t sebesar 0,576 dengan tingkat signifikan 0,569 lebih besar dari a 0,05 (5\%). Hal ini menunjukan bahwa tanggung jawab sosial perusahaan di bidang Kesehatan tidak berpengaruh signifikan terhadap Net Income perusahaan. Dengan demikian, hipotesis alternative (HA3) yang menyatakan bahwa CSR dibidang kesehatan berpengaruh terhadap Net Income perusahaan ditolak.

Berdasarkan hasil pengujian secara simultan menghasilkan nilai $F$ hitung sebesar 44,533 dengan tingkat signifikasi 0,000 lebih kecil dari taraf signifikasi a 0,5 (5\%). Hal ini membuktikan bahwa hipotesis alternative Ha yang menyatakan bahwa CSR (Lingkungan, kesehatan, masyarakat) secara bersama-sama berpengaruh terhadap Net Income perusahaan di terima. Dengan demikian dapat disimpulkan bahwa CSR (Lingkungan, kesehatan, masyarakat) secara bersama-sama berpengaruh terhadap Net Income perusahaan. 


\section{PEMBAHASAN}

Hasil Uji t untuk variable lingkungan, kesehatan, masyarakat menyatakan hasil yang tidak signifikan, karena nilai tingkat signifikansi masing-masing variable lebih besar dari 0,05 atau $5 \%$. Hal ini menunjukan bahwa hipotesis yang mengatakan bahwa CSR lingkungan, kesehatan, masayarakat berpengaruh terhadap Net Income perusahaan ditolak.

Hasil penelitian ini didukung oleh temuan Rockness et.al (1986). Dan juga didukung oleh temuan susi (2005) yang menemukan hubungan yang tidak signifikan antara economic performance financial performance. Hasil tersebut juga di dukung oleh penelitian Titisari et.al (2010) yang menyatakan bahwa CSR tidak berpengaruh signifikan terhadap kinerja keuangan yang diukur dengan stockreturn.

Sebaliknya, temuan di atas tidak konsisten dengan temuan Bragdon dan Marlin (1972), Spicer (1978), Feedman dan Jaggi (1992), Al-Tuwaijri, et.al.(2004), Suratno (2006) dan Nuraini (2010) yangmenyatakan bahwa CSR berpengaruh terhadap kinerja keuangan perusahaan.

Hasil uji $\mathrm{F}$ menunjukan tingkat signifikansi sebesar 0,000 berarti berada di bawah taraf signifikan 0,05. Hal ini menunjukan bahwa hipotesis yang mengatakan bahwa CSR (Lingkungan, kesehatan, masyarakat) secara bersama-sama berpengaruh terhadap Net Income perusahaan diterima.

\section{KESIMPULAN}

Berdasarkan analisis data, maka dapat ditarik kesimpulan sebagai berikut:

a. CSR (Lingkungan) berpengaruh signifikan terhadap Net Income perusahaan

b. CSR (masyarakat) tidak berpengaruh siginfikan terhadap Net Income perusahaan

c. CSR (kesehatan) tidak berpengaruh signifikan terhadap Net Income perusahaan.

d. CSR (Lingkungan,Masyarakat,Kesehatan) secara bersama-sama tidak berpengaruh signifikan terhadap Net Income Perusahaan.

\section{Keterbatasan dan Saran}

Jenis perusahaan yang digunakan sebagai sample hanya satu perusahaan dengan menggunakan Annual Report tahun pengamatan 2012,2013,2014, serta variabel untuk mengukur kinerja keuangan perusahaan dengan Net Income, oleh karena itu disarankan untuk peneliti selanjutnya dapat menambah jenis perusahaan periode penelitian, menggunakan variabel lain seperti variabel control ataupun variabel pemoderasi, dan untuk tahun penelitian untuk selalu di upgread atau memakai tahun yang paling baru.

\section{DAFTAR PUSTAKA}

Hhtp://id. Wikipedia.org/wiki/

Hhtp://id.vivanews.com (3 februari 2009)

Jalal, 2009, Kesalahpahaman Tentang Tanggung Jawab Sosial Perusahaan, Harian Tempo, 15 Januari

Jefkins, F , 2003, Publick Relation, Erlangga. Jakarta.

Kartini, D .2008.Coorporate Social Responbility. Transformasi Konsep Sustainable Management dan implementasi di Indonesia, Refika Aditama, bandung.

Kotler, P,N. Lee.2005 Coorporate Social Responbility: Doing the most Good for your Company and your cause, John Wiley \& Sons Inc, New Jersey. 
Nazir, M. 2005, Metode Penelitian, Ghalia Indonesia, Jakarta.

News of PERHUMAS. 2004. CSR dan Citra Corporate. http://www.perhumas.or.id/ (5 september 2010).

Nugroho, B.A. 2005, memilih Metode Statistik penelitian dengan SPSS, Penerbit .

Panggabean, M.F, 2009, pengaruh Kegiatan Filantropi Perusahaan Terhadap Citra Medco (studi kajian bidang pendidikan), Skiripsi padan Jurusan. Fakultas Ilmu Sosial dan Ilmu Politik, Universitas Indonesia, Depok.

Picton, D, A, Broderick. 2001. Integrated Marketing Comunications. LexisNexis. Canada.

Prasetijo, Budimanta, Rudito. 2004. Corporate Social responbility, jawaban BagiModel Pembangunan Indonesia Masa Kini. Jakarta.

Prasetya, F.E, 2010, Analisis Pengaruh Corporate Social Responbility" Lifebouy Berbagi Sehat" Terhadap Loyalitas Konsumen dan Citra perusahaan Unilever Indonesia (studi Kasus di Kota Bogor), Departemen Manajemen, Fakultas Ekonomi dan Manajmen.Institut Pertanian Bogor. Bogor.

Rakhmat, J. 2000. Metode Penelitian Komunikasi, Rosdakarya, Bandung.

Roslina. 2010. Citra Merek: Dimensi,Proses Pengembangan serata Pengukuranya, Dalam Jurnal Bisnis \& Manajemen vol.6 no.3.Siregar, C.N. 2007.

Sugiyono, 2004, Metode Penelitian Bisnis, Affabeta, Bandung.

Suharto, E, 2006, Tanggung Jawab Sosial dan Comdev.

Suharto, E, 2007, Pekerjaan Sosial Di Dunia Industri, RefikaAditama. Bandung

Suharto, E, 2008, Menggagas Standar Audit Program CSR.

Seravina, M. 2008. Pengaruh Penerapan Corporate Social Responbility (CSR) Terhadap Loyalitas Nasabah Tabungan Britama (Studi Kasus Pada Nasabah PT. Bank Rakyat Indonesia (Persero) Tbk. Cabang Bogor.,

Solihin, I. 2008 Corporate Social Responbility: From Charity to Sustainability. Salemba Empat, Jakarta.

Undang-Undang No.40 Tahun 2007 Tentang Perseroan Terbatas

Undang-undang No.25 Tahun 2007 Tentang Penanaman Modal

Umar, H, 2003, Metode Riset perilaku konsumen Jasa.Ghalia Indonesia, Jakarta 